\title{
Phase C Flygt Mixer Test Results
}

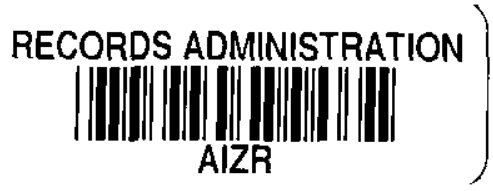

by

M. R. Poirier

Westinghouse Savannah River Company

Savannah River Site

Aiken, South Carolina 29808

P. O. Rodwell

This paper was prepared in connection with work done under the above contract number with the U. S. Department of Energy. By acceptance of this paper, the publisher and/or recipient acknowledges the U. S. Government's right to retain a nonexclusive, royalty-free license in and to any copyright covering this paper, along with the right to reproduce and to authorize others to reproduce all or part of the copyrighted paper. 


\section{DISCLAIMER}

This report was prepared as an account of work sponsored by an agency of the United States Government. Neither the United States Government nor any agency thereof, nor any of their employees, makes any warranty, express or implied, or assumes any legal liability or responsibility for the accuracy, completeness, or usefulness of any information, apparatus, product, or process disclosed, or represents that its use would not infringe privately owned rights. Reference herein to any specific commercial product, process, or service by trade name, trademark, manufacturer, or otherwise does not necessarily constitute or imply its endorsement, recommendation, or favoring by the United States Government or any agency thereof. The views and opinions of authors expressed herein do not necessarily state or reflect those of the United States Government or any agency thereof.

This report has been reproduced directly from the best available copy.

Available to DOE and DOE contractors from the Office of Scientific and Technical Information, P.O. Box 62, Oak Ridge, TN 37831; prices available from (615) 576-8401.

Available to the public from the National Technical Information Service, U.S. Department of Commerce, 5285 Port Royal Road, Springfield, VA 22161. 
KEYWORDS: Waste Removal, Flygt mixer, Tank 19

RETENTION: Permanent

\section{Phase C Flygt Mixer Test Results (U)}

M. R. Poirier

P. O. Rodwell

March 26, 1999

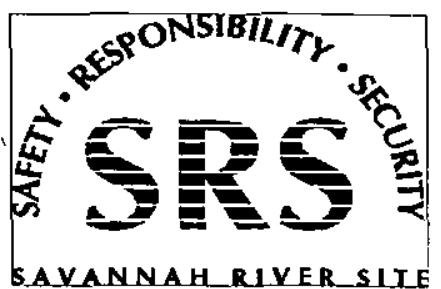




\section{Summary}

The Savannah River Site (SRS) teamed with the Pacific Northwest National Laboratory (PNNL), Oak Ridge National Laboratory (ORNL), and ITT Flygt Corporation to conduct a test program evaluating shrouded axial propeller mixers (Flygt mixers) for heel removal in SRS Tank 19. The team performed tests with $50 \mathrm{hp}$ mixers in the $85 \mathrm{ft}$ diameter Full Tank at SRS. The significant results and conclusions of this test are:

- The SRS stationary mixer deployment mast testing was successful in allowing simple, efficient mixer installation through the riser opening. Once within the tank, the mixer manually reoriented to its horizontal operating position. The mast kept the $50 \mathrm{hp}$ mixer stable on the tank floor during operation. With external crane support, the mast was lifted and redirected to discharge in another direction.

- Three stationary Flygt mixers will not successfully suspend zeolite in an SRS waste tank.

- The test results indicate that three mixers should successfully suspend zeolite and lighter sludge components in SRS waste tanks provided the mixers can rotate from horizontal positions on the tank floor and are equipped with modified shrouds to focus the mixer discharge.

- Typical average fluid velocities at the center of the tank (measured 7 feet from center) were $0.35-1.28$ feet/second.

- Typical average velocities at the tank wall were $1.1-4.5$ feet/second.

- The jet produced by the Flygt mixer spreads wider and decays faster than a classical turbulent jet.

- The measured fluid velocities increased when the tank liquid level was decreased.

\section{Introduction}

SRS is identifying and investigating techniques to remove sludge heels from waste tanks such as Tank 19. Shrouded axial propeller mixers manufactured by ITT Flygt Corporation are one of the suggested alternatives. The mixers consist of an electrically powered propeller surrounded by a close-fitting shroud (see Figure 1). The $50 \mathrm{hp} \mathrm{mixers} \mathrm{being} \mathrm{considered} \mathrm{for} \mathrm{waste} \mathrm{retrieval} \mathrm{in}$ Tank 19 have a propeller diameter of 20 inches and a maximum speed of $860 \mathrm{rpm}$. The rapidly spinning propeller creates a turbulent jet with an average exit velocity of approximately $20 \mathrm{ft} / \mathrm{sec}$.

SRS, PNNL, ORNL, and ITT Flygt are conducting a mixer test program to evaluate the ability of Flygt mixers to retrieve waste from SRS Tank 19, and other DOE site waste tanks. The team performed the first phase of tests at the ITT Flygt laboratory in Trumbull, CT with a $1.5 \mathrm{ft}$ diameter tank. ${ }^{1}$ The second phase of tests was performed with PNNL's pilot-scale mixing tanks ( $6 \mathrm{ft}$ diameter and $18.75 \mathrm{ft}$ diameter) in Hanford, WA. ${ }^{2}$ The third test phase was performed with the TNX Full Tank ( $85 \mathrm{ft}$ diameter) at SRS. Tests are performed with different size tanks so scaling methods can be developed to apply the test results to real waste tanks.

\section{Test Description}

Because of cost and waste disposal issues, tests were performed with water in the TNX full tank. Water was added to the tank and mixed with the Flygt mixers. Fluid velocities were measured throughout the tank and compared with predictions from smaller scale tests. The purpose of the 
tests was to determine whether the mixers provide sufficient velocity throughout the tank to suspend zeolite and sludge.

Table 1 shows the mixer configurations tested. In the table, $\mathrm{CW}$ indicates the mixer was discharging fluid at an angle $30^{\circ}$ off the tank centerline and in the clockwise direction. CCW indicates the mixer was discharging fluid at an angle $30^{\circ}$ off the tank centerline and in the counterclockwise direction. $T$ indicates the mixer was positioned to discharge fluid transverse (approximately $10^{\circ}$ off the center of the tank). The mixer positions are given in polar coordinates, with zero degrees being the position of the center of the support structure located on the south side of the tank which holds slurry pumps in the tank. Figure 2 shows the mixer layout from Test 4.

Table 1. Mixer Configurations

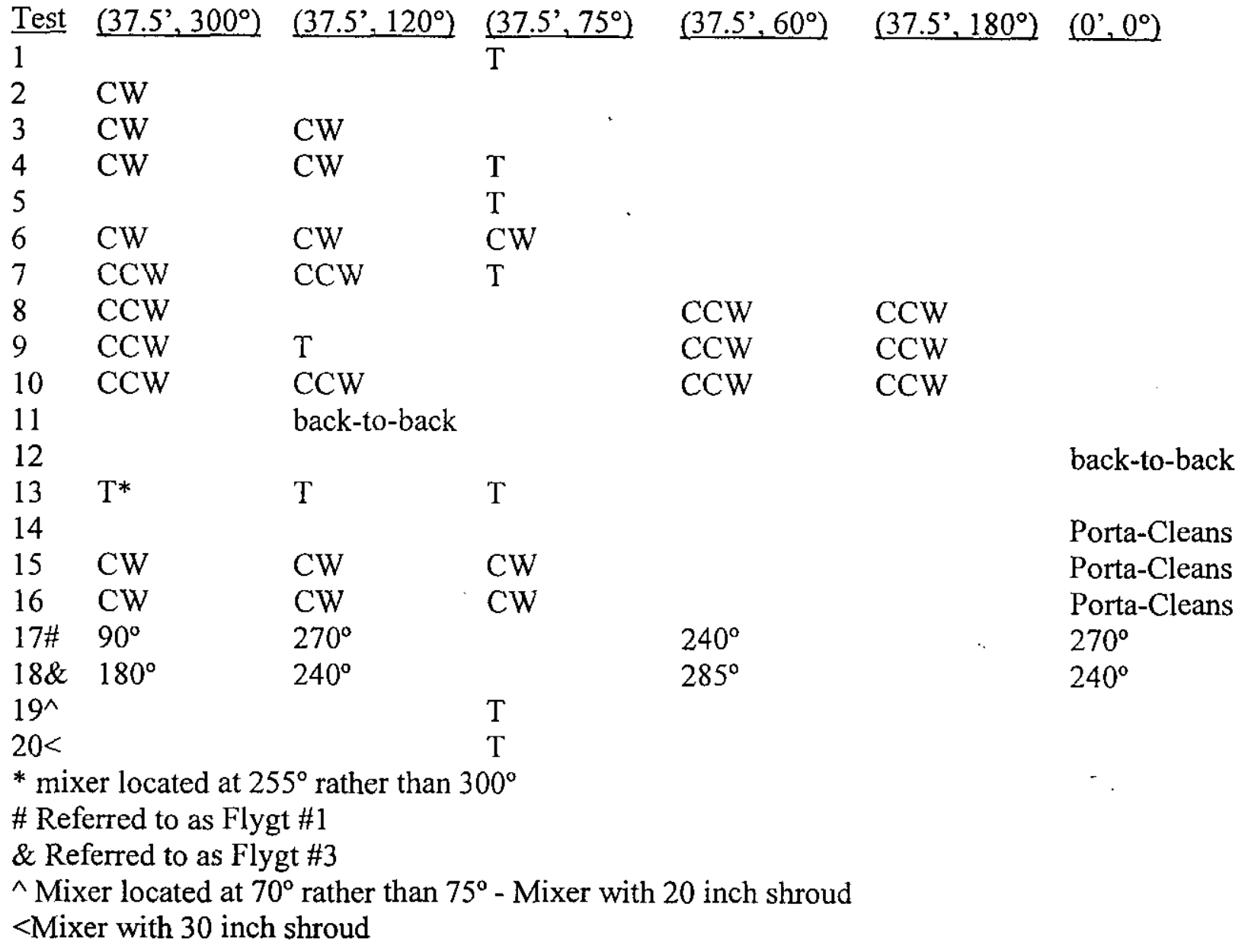

The liquid level in the tank during testing was 4 feet, except during tests 1,9,15, and 16 . During tests 1 and 9 , velocity data was collected with tank levels of 3 feet, 4 feet, and 6 feet. During tests 15 and 16 , the water level was 5.5 feet.

The mixer located at $37.5 \mathrm{ft}$. and $300^{\circ}$ (see Figure 2) was inserted into the tank through a riser to test deployment of the insertion mast and mixer operation from that mast. 
The tests were performed by operating the mixers at full speed and measuring the fluid velocity at various positions in the tank. Fluid velocities were measured with the Marsh-McBirney model 511 electromagnetic velocity probe used in Phase B testing ${ }^{2}$ and recorded with a Strawberry Tree data acquisition system at $10 \mathrm{~Hz}$ for $2-5$ minutes. During test 1 , the velocity was measured at distances of 15-75 feet from the mixer discharge, along the jet centerline, and at 10 and 20 degrees off the centerline (at same height as jet centerline). Table 2 shows the positions at which the fluid velocities were measured during tests $2-18$. In tests $2-18$, the velocity was measured 2 inches above the tank bottom. During tests 19 and 20, the velocity was measured at distances of 25-70 feet from the mixer discharge, along the jet centerline, 2 inches above the tank bottom, and at 10 and 20 degrees off the centerline (at same height as jet centerline). The probe was oriented so the $y$-axis is parallel to the cat walk and the $\mathrm{x}$-axis is perpendicular to the cat walk. The purpose of the tests is to validate the computational fluid dynamics modeling performed by ITT Flygt, and to determine whether the fluid velocity in the tank exceeds the minimum velocity required to suspend zeolite and sludge which was identified in the Phase A and Phase B tests. ${ }^{1,2}$

Table 2. Velocity Measurement Positions for tests 2 - 18

\begin{tabular}{|c|c|c|c|c|}
\hline Radius & Angle & Angle & Angle & Angle \\
\hline $0 \mathrm{ft}$ & $270^{\circ}$ & $90^{\circ}$ & $180^{\circ}$ & $210^{\circ}$ \\
\hline $14 \mathrm{ft}$ & $270^{\circ}$ & $90^{\circ}$ & $180^{\circ}$ & $210^{\circ}$ \\
\hline $28 \mathrm{ft}$ & $270^{\circ}$ & $90^{\circ}$ & $180^{\circ}$ & $210^{\circ}$ \\
\hline $42 \mathrm{ft}$ & $270^{\circ}$ & $90^{\circ}$ & $180^{\circ}$ & $210^{\circ}$ \\
\hline
\end{tabular}

\section{Results}

Appendix A contains the velocity data from the tests. The data shows the time averaged velocity, the turbulent intensity, and the location of the reading. The velocity is the square root of the sum of the squares of the $x$ and $y$ components of the velocity. The turbulent intensity is the fluctuating component of the velocity divided by the average velocity. In some of the tests, the turbulent intensities and peak velocities measured were much higher than expected and appear to indicate some type of problem with the velocity probe or data acquisition system. The data from these tests. are being evaluated and are not discussed further in this report. The following observations and conclusions were made from the data in this test:

Mixer discharge profile

- The average discharge velocity measured with a standard shroud was about $20 \%$ of the value predicted based upon turbulent jet theory.

- Turbulent jet theory predicts the fluid velocity measured 10 degrees off the jet centerline should be less than $50 \%$ of the velocity at the centerline. In the tests with standard shrouds, the measured velocities 10 degrees and 20 degrees off the centerline were approximately equal to and in some cases exceeded the centerline velocity. The results indicate the jet produced by the Flygt mixer spreads wider than a classical turbulent jet. Visual observations of the mixer discharge support this conclusion.

- In the test with the extended shrouds, the fluid velocity measured 2 inches above the tank bottom was approximately equal to the fluid velocity measured at the jet centerline.

- The measured fluid velocities increased when the tank liquid level was decreased. 
- The turbulent intensity (fluctuating velocity divided by average velocity) was measured. Many of the readings were in the range of $0.30-0.60$. Typical turbulent intensities for turbulent jets are approximately 0.30 . Measured intensities in agitated tanks are approximately 0.35 . These intensities are slightly higher than expected. The differences could be due to the waves circulating around the tank, the variations in flow caused by the rotating propellers, or surface agitation.

- If the mixers are to be rotated to improve solids suspension, the mixer shrouds should be modified to narrow the jet, reduce the axial velocity decay, and increase the cleaning radius.

- Tests performed after extending the shroud on the Flygt mixer to 20 inches showed the centerline velocity increased approximately 50\%. Increasing the shroud length to 30 inches caused a decrease in the jet velocity. This decrease is most likely due to the increased resistance of the shroud. Additional work should be performed to optimize the shroud design.

Tank velocity with multiple mixers

- Typical average fluid velocities at the center of the tank (measured 7 feet from center) were $0.35-1.28 \mathrm{feet} /$ second. The one large reading at the center (test \#4) was due to the velocity probe being in the mixer discharge.

- Typical average velocities at the tank wall were $1.14-4.51$ feet/second. The low velocity readings at the wall in test \#5 are because only a single transverse mixer was used.

- Turbulent intensities in most tests were $0.09-0.68$.

\section{Conclusions}

- The SRS stationary mixer deployment mast testing was successful in allowing simple, efficient mixer installation through the riser opening. Once within the tank, the mixer manually reoriented to its horizontal operating position. The mast kept the $50 \mathrm{hp}$ mixer stable on the tank floor during operation. With external crane support, the mast was lifted and redirected to discharge in another direction.

- Three stationary Flygt mixers will not successfully suspend zeolite in an SRS waste tank.

- The test results indicate three mixers should successfully suspend zeolite and lighter sludge components in SRS waste tanks provided the mixers can rotate from horizontal positions on the tank floor and are equipped with modified shrouds to focus the mixer discharge.

The full Phase $\mathrm{C}$ test report will provide a more complete evaluation of test program results and conclusions.

\section{References}

1. M. R. Powell, J. R. Farmer, H. Gladki, B. K. Hatchell, M. R. Poirier, and P. O. Rodwell, "Evaluation of Flygt Mixers for Application in Savannah River Site Tank 19 Test Results from Phase A: Small-Scale Testing at ITT Flygt", PNNL-12094, March 1999.

2. M. R. Powell, W. H. Combs, J. R. Farmer, H. Gladki, B. K. Hatchell, M. A. Johnson, M. R. Poirier, and P. O. Rodwell, "Evaluation of Flygt Mixers for Application in Savannah River Site Tank 19 Test Results from Phase B: Mid-Scale Testing at PNNL", PNNL-12093, March 1999. 


\section{Appendix A \\ Test Data}

Velocity is average velocity

Turbulent intensity is fluctuating velocity component divided by average velocity ( $u$ '/U)

Axial distance is distance from mixer discharge to velocity probe along the centerline

Angle is the angle between the discharge centerline and the line between the mixer and the velocity probe

Water level is $4 \mathrm{ft}$ except for $1 \mathrm{a}(6 \mathrm{ft})$ and $1 \mathrm{c}(3 \mathrm{ft})$

Test \#1a

\begin{tabular}{|c|c|c|c|}
\hline Velocity & Turbulent Intensity & Axial Distance & Angle \\
\hline $1.55 \mathrm{ft} / \mathrm{s}$ & .33 & $15 \mathrm{ft}$ & 0 degrees \\
\hline 1.30 & .40 & 20 & 0 \\
\hline 1.42 & .42 & 25 & 0 \\
\hline 1.35 & .36 & 30 & 0 \\
\hline 1.40 & .32 & 35 & 0 \\
\hline 1.26 & .45 & 40 & 0 \\
\hline 1.05 & .50 & 45. & 0 \\
\hline 0.48 & .58 & 50 & 0 \\
\hline 0.28 & .58 & 55 & 0 \\
\hline 0.38 & .62 & 60 & 0 \\
\hline 0.36 & .40 & 65 & 0 \\
\hline 0.56 & .37 & 70 & 0 \\
\hline 0.55 & 3.34 & 75 & 0 \\
\hline 136 & & & \\
\hline 1.36 & .67 & 20 & 10 \\
\hline 1.29 & .38 & 25 & 10 \\
\hline 1.26 & .42 & 30 & 10 \\
\hline 1.07 & .44 & 35 & 10 \\
\hline 0.92 & .50 & 40 & 10 \\
\hline 0.54 & .56 & 45 & 10 \\
\hline 0.32 & .57 & 50 & 10 \\
\hline 0.31 & .48 & 55 & 10 \\
\hline 0.26 & .51 & 60 & 10 \\
\hline 0.42 & .66 & 65 & 10 \\
\hline 0.46 & .55 & 70 & 10 \\
\hline 2.70 & .36 & 20 & 20 \\
\hline 2.23 & .41 & 25 & 20 \\
\hline 1.90 & .39 & 30 & 20 \\
\hline 1.62 & .40 & 35 & 20 \\
\hline 1.05 & .58 & 40 & 20 \\
\hline 1.01 & .47 & 45 & 20 \\
\hline 0.43 & .73 & 50 & 20 \\
\hline
\end{tabular}


Test\#1b

\begin{tabular}{|l|l|l|l|}
\hline Velocity & Turbulent Intensity & Axial Distance & Angle \\
\hline $2.78 \mathrm{ft} / \mathrm{s}$ & .20 & $30 \mathrm{ft}$ & 0 degrees \\
\hline 2.29 & .32 & 35 & 0 \\
\hline 1.69 & .55 & 40 & 0 \\
\hline 1.67 & .58 & 45 & 0 \\
\hline 2.11 & .48 & 50 & 0 \\
\hline 1.36 & .45 & 55 & 0 \\
\hline 1.35 & .63 & 60 & 0 \\
\hline 1.27 & .42 & 65 & 0 \\
\hline 1.39 & .69 & 70 & 0 \\
\hline 1.36 & .95 & 75 & 0 \\
\hline & & & \\
\hline 2.34 & .46 & 30 & 10 \\
\hline 2.57 & .34 & 35 & 10 \\
\hline 1.87 & .47 & 40 & 10 \\
\hline 1.85 & .53 & 45 & 10 \\
\hline 1.88 & .57 & 50 & 10 \\
\hline 1.79 & .61 & 55 & 10 \\
\hline 1.55 & .76 & 60 & 10 \\
\hline 1.39 & .79 & 65 & 10 \\
\hline 1.58 & .97 & 70 & 10 \\
\hline & & & \\
\hline 2.34 & .55 & 30 & 20 \\
\hline 2.03 & .62 & 35 & 20 \\
\hline 2.05 & .46 & 40 & 20 \\
\hline 1.15 & .65 & 45 & 20 \\
\hline 0.66 & .87 & 50 & 20 \\
\hline 0.71 & .85 & 55 & 20 \\
\hline 0.41 & .84 & 60 & 20 \\
\hline 0.35 & .61 & 65 & 20 \\
\hline & & & \\
\hline & & & \\
\hline & & & \\
\hline
\end{tabular}




Test \#1c
\begin{tabular}{|l|l|l|l|}
\hline Velocity & Turbulent Intensity & Axial Distance & Angle \\
\hline $3.45 \mathrm{ft} / \mathrm{s}$ & .35 & $30 \mathrm{ft}$ & 0 degrees \\
\hline 3.21 & .38 & 35 & 0 \\
\hline 2.57 & .68 & 40 & 0 \\
\hline 2.61 & .55 & 45 & 0 \\
\hline 2.42 & .48 & 50 & 0 \\
\hline & & & \\
\hline & & & \\
\hline & & & \\
\hline 1.29 & .70 & 70 & 0 \\
\hline 1.64 & .73 & 75 & 0 \\
\hline & & & \\
\hline 3.29 & .44 & 30 & 10 \\
\hline 2.75 & .59 & 35 & 10 \\
\hline 1.74 & .61 & 40 & 10 \\
\hline 2.63 & .67 & 45 & 10 \\
\hline 2.62 & .55 & 50 & 10 \\
\hline 2.13 & .39 & 55 & 10 \\
\hline 2.04 & .47 & 60 & 10 \\
\hline 1.95 & .65 & 65 & 10 \\
\hline 1.88 & .57 & 70 & 10 \\
\hline & & & \\
\hline 2.38 & .65 & 30 & 20 degrees \\
\hline 1.61 & .66 & 35 & 20 \\
\hline
\end{tabular}

Test\#2

\begin{tabular}{|l|l|l|l|}
\hline $\begin{array}{l}\text { Velocity (ft/s) } \\
-1\end{array}$ & Turbulent Intensity & $\begin{array}{l}\text { Distance From Tank } \\
\text { Center }\end{array}$ & Angle \\
\hline 1.61 & .16 & 14 & 90 \\
\hline 1.24 & .18 & 28 & 90 \\
\hline 2.95 & .16 & 42 & 90 \\
\hline 1.50 & .12 & 14 & 180 \\
\hline 1.27 & .10 & 28 & 180 \\
\hline 2.70 & .10 & 42 & 180 \\
\hline 1.42 & .11 & 14 & 210 \\
\hline 1.22 & .12 & 28 & 210 \\
\hline 2.57 & .15 & 42 & 210 \\
\hline 1.27 & .15 & 14 & 270 \\
\hline 1.30 & .46 & 28 & 270 \\
\hline 1.86 & .09 & 42 & 270 \\
\hline 0.46 & .35 & 7 & 270 \\
\hline
\end{tabular}


Test\#3

\begin{tabular}{|l|l|l|l|}
\hline Velocity (ft/s) & Turbulent Intensity & $\begin{array}{l}\text { Distance From Tank } \\
\text { Center }\end{array}$ & Angle \\
\hline .61 & .53 & 7 & 90 \\
\hline .98 & .32 & 14 & 90 \\
\hline 1.45 & .38 & 28 & 90 \\
\hline 3.18 & .21 & 42 & 90 \\
\hline .35 & .43 & 7 & 180 \\
\hline .40 & .38 & 14 & 180 \\
\hline 1.58 & .2 & 28 & 180 \\
\hline & & 42 & 180 \\
\hline & & 7 & 210 \\
\hline .46 & .41 & 14 & 210 \\
\hline 1.98 & .16 & 28 & 210 \\
\hline 3.10 & .10 & 42 & 210 \\
\hline .35 & .41 & 7 & 270 \\
\hline .53 & .36 & 14 & 270 \\
\hline 1.90 & .13 & 28 & 270 \\
\hline 2.91 & .09 & 42 & 270 \\
\hline
\end{tabular}

Test\#4

\begin{tabular}{|l|l|l|l|}
\hline Velocity (ft/s) & Turbulent Intensity & $\begin{array}{l}\text { Distance From Tank } \\
\text { Center }\end{array}$ & Angle \\
\hline 3.75 & .14 & 7 & 90 \\
\hline 5.28 & .26 & 14 & 90 \\
\hline 1.66 & .14 & 28 & 90 \\
\hline 1.14 & .31 & 42 & 90 \\
\hline 1.28 & .24 & 7 & 180 \\
\hline 1.39 & .19 & 14 & 180 \\
\hline 1.85 & .19 & 28 & 180 \\
\hline 3.23 & .14 & 42 & 180 \\
\hline 1.23 & .25 & 7 & 210 \\
\hline 1.42 & .15 & 14 & 210 \\
\hline 1.98 & .12 & 28 & 210 \\
\hline 3.01 & .11 & 42 & 210 \\
\hline 1.15 & .23 & 7 & 270 \\
\hline 1.43 & .25 & 14 & 270 \\
\hline 1.89 & .10 & 28 & 270 \\
\hline 2.78 & .12 & 42 & 270 \\
\hline
\end{tabular}


Test\#5

\begin{tabular}{|l|l|l|l|}
\hline Velocity $(\mathrm{ft} / \mathrm{s})$ & Turbulent Intensity & $\begin{array}{l}\text { Distance From Tank } \\
\text { Center }\end{array}$ & Angle \\
\hline .56 & .55 & 7 & 90 \\
\hline .97 & .54 & 14 & 90 \\
\hline 5.08 & .26 & 28 & 90 \\
\hline .57 & .45 & 42 & 90 \\
\hline .39 & .41 & 7 & 180 \\
\hline .34 & .53 & 14 & 180 \\
\hline .65 & .36 & 28 & 180 \\
\hline 1.43 & .21 & 42 & 180 \\
\hline .47 & .30 & 7 & 210 \\
\hline .34 & .29 & 14 & 210 \\
\hline .96 & .22 & 28 & 210 \\
\hline 1.24 & .24 & 42 & 210 \\
\hline 1.02 & .24 & 7 & 270 \\
\hline .93 & .15 & 14 & 270 \\
\hline .81 & .17 & 28 & 270 \\
\hline 1.07 & .18 & 42 & 270 \\
\hline
\end{tabular}

Test\#6

\begin{tabular}{|l|l|l|l|}
\hline Velocity $(\mathrm{ft} / \mathrm{s})$ & Turbulent Intensity & $\begin{array}{l}\text { Distance From Tank } \\
\text { Center }\end{array}$ & Angle \\
\hline 1.24 & .45 & 7 & 90 \\
\hline 2.01 & .13 & 14 & 90 \\
\hline 5.64 & .22 & 28 & 90 \\
\hline 4.51 & .35 & 42 & 90 \\
\hline 1.05 & .30 & 7 & 180 \\
\hline 1.66 & .29 & 14 & 180 \\
\hline 1.99 & .17 & 28 & 180 \\
\hline 1.40 & .49 & 42 & 180 \\
\hline 1.11 & .24 & 7 & 210 \\
\hline 1.77 & .14 & 14 & 210 \\
\hline 1.94 & .13 & 28 & 210 \\
\hline 1.53 & .27 & 42 & 210 \\
\hline 1.17 & .31 & 7 & 270 \\
\hline 1.98 & .13 & 14 & 270 \\
\hline 1.98 & .11 & 28 & 270 \\
\hline 1.68 & .17 & 42 & 270 \\
\hline
\end{tabular}


Test\#9b

\begin{tabular}{|l|l|l|l|}
\hline Velocity (ft/s) & Turbulent Intensity & $\begin{array}{l}\text { Distance From Tank } \\
\text { Center }\end{array}$ & Angle \\
\hline .91 & .57 & 7 & 90 \\
\hline 1.16 & .32 & 14 & 90 \\
\hline 1.68 & .38 & 28 & 90 \\
\hline 3.51 & .17 & 42 & 90 \\
\hline .64 & .52 & 7 & 180 \\
\hline 1.40 & .24 & 14 & 180 \\
\hline 2.00 & .15 & 28 & 180 \\
\hline 2.98 & .39 & 42 & 180 \\
\hline .55 & .68 & 7 & 210 \\
\hline 1.15 & .26 & 14 & 210 \\
\hline 1.97 & .17 & 28 & 210 \\
\hline 1.58 & .38 & 42 & 210 \\
\hline .46 & .47 & 7 & 270 \\
\hline 1.17 & .33 & 14 & 270 \\
\hline 2.14 & .12 & 28 & 270 \\
\hline 2.54 & .16 & 42 & 270 \\
\hline
\end{tabular}

Test\#11

\begin{tabular}{|l|l|l|l|}
\hline Velocity (ft/s) & Turbulent Intensity & $\begin{array}{l}\text { Distance From Tank } \\
\text { Center }\end{array}$ & Angle \\
\hline 1.73 & .81 & 7 & 90 \\
\hline 1.51 & .21 & 14 & 90 \\
\hline 3.94 & .45 & 28 & 90 \\
\hline 1.95 & .44 & 42 & 90 \\
\hline .44 & 1.07 & 7 & 180 \\
\hline .54 & .87 & 14 & 180 \\
\hline .82 & .50 & 28 & 180 \\
\hline 1.91 & .23 & 42 & 180 \\
\hline .48 & .56 & 7 & 210 \\
\hline .50 & .66 & 14 & 210 \\
\hline 1.45 & .21 & 28 & 210 \\
\hline 1.97 & .15 & 42 & 210 \\
\hline .79 & .17 & 7 & 270 \\
\hline .75 & .38 & 14 & 270 \\
\hline 1.23 & .18 & 28 & 270 \\
\hline 2.04 & .13 & 42 & 270 \\
\hline & & &
\end{tabular}


Test \#19 (20 inch shroud)

\begin{tabular}{|c|c|c|c|c|}
\hline $\begin{array}{l}\text { Velocity } \\
(\mathrm{ft} / \mathrm{s})\end{array}$ & $\begin{array}{l}\text { Turbulent } \\
\text { Intensity }\end{array}$ & $\begin{array}{l}\text { Max Velocity } \\
(\mathrm{ft} / \mathrm{s})\end{array}$ & $\begin{array}{l}\text { Axial Distance } \\
\text { (ft) }\end{array}$ & $\begin{array}{l}\text { Angle } \\
\text { (degrees) }\end{array}$ \\
\hline 2.75 & .36 & 9.52 & 25 & 0 \\
\hline 3.93 & .69 & 23.41 & 25 & Bottom \\
\hline 3.98 & .66 & 26.60 & 25 & Bottom \\
\hline 2.48 & .58 & 9.84 & 30 & 0 \\
\hline 3.13 & .55 & 18.82 & 30 & Bottom \\
\hline 3.11 & .64 & 17.95 & 30 & Bottom \\
\hline 2.70 & .50 & 20.83 & 35 & 0 \\
\hline 4.12 & .99 & 32.49 & 35 & Bottom \\
\hline 3.37 & .88 & 30.14 & 35 & Bottom \\
\hline 2.05 & .46 & 7.62 & 40 & 0 \\
\hline 3.40 & .99 & 33.29 & 40 & Bottom \\
\hline 2.63 & .46 & 7.48 & 45 & 0 \\
\hline 2.16 & .64 & 13.23 & 45 & Bottom \\
\hline 2.47 & .54 & 9.95 & 50 & 0 \\
\hline 2.26 & .62 & 9.02 & 50 & Bottom \\
\hline 2.13 & .47 & 7.04 & 55 & 0 \\
\hline 2.15 & .53 & 9.27 & 55 & Bottom \\
\hline 2.32 & .47 & 9.35 & 60 & 0 \\
\hline 2.27 & .52 & 9.10 & 60 & Bottom \\
\hline 2.33 & .50 & 7.22 & 65 & 0 \\
\hline 2.74 & .39 & 8.34 & 65 & Bottom \\
\hline 2.22 & .66 & 8.78 & 70 & 0 \\
\hline 2.75 & .48 & 9.04 & 70 & Bottom \\
\hline 3.33 & .35 & 8.38 & 25 & 10 \\
\hline 3.19 & .42 & 12.00 & 30 & 10 \\
\hline 2.86 & .37 & 7.89 & 35 & 10 \\
\hline 2.15 & .59 & 8.29 & 40 & 10 \\
\hline 2.46 & .51 & 7.85 & 45 & 10 \\
\hline 2.14 & .59 & 8.36 & 50 & 10 \\
\hline 2.10 & .60 & 8.85 & 55 & 10 \\
\hline 2.52 & .56 & 8.92 & 60 & 10 \\
\hline $2: 14$ & .54 & 8.08 & 65 & 10 \\
\hline 3.83 & .22 & 8.50 & $\overline{25}$ & 20 \\
\hline 3.47 & .27 & 8.65 & 30 & 20 \\
\hline 2.80 & .46 & 9.13 & 35 & 20 \\
\hline 2.71 & .55 & 13.45 & 40 & 20 \\
\hline 2.13 & .63 & 7.43 & 45 & 20 \\
\hline 2.37 & .68 & 11.33 & 50 & 20 \\
\hline 2.35 & .64 & 9.09 & 55 & 20 \\
\hline 2.33 & .63 & 9.87 & 60 & 20 \\
\hline
\end{tabular}


Test 20 (30 inch Shroud)

\begin{tabular}{|l|l|l|l|l|}
\hline $\begin{array}{c}\text { Average Velocity } \\
(\mathrm{ft} / \mathrm{sec})\end{array}$ & \multicolumn{1}{|c|}{$\begin{array}{c}\text { Turbulent } \\
\text { Intensity }\end{array}$} & $\begin{array}{c}\text { Maximum Velocity } \\
(\mathrm{ft} / \mathrm{sec})\end{array}$ & \multicolumn{1}{|c|}{$\begin{array}{c}\text { Distance } \\
(\mathrm{ft})\end{array}$} & \multicolumn{1}{|c|}{$\begin{array}{c}\text { Angle } \\
\text { (degrees) }\end{array}$} \\
\hline 2.80 & .26 & 4.42 & 25 & 0 \\
\hline 4.09 & .12 & 5.45 & 25 & Bottom \\
\hline 2.05 & .43 & 4.15 & 30 & 0 \\
\hline 3.46 & .13 & 5.36 & 30 & Bottom \\
\hline 3.11 & .13 & 4.48 & 35 & 0 \\
\hline 3.19 & .13 & 4.43 & 35 & Bottom \\
\hline 2.57 & .17 & 3.75 & 40 & 0 \\
\hline 1.76 & .33 & 3.07 & 40 & Bottom \\
\hline 1.95 & .19 & 2.98 & 45 & 0 \\
\hline 1.68 & .22 & 3.21 & 45 & Bottom \\
\hline 1.14 & .36 & 2.29 & 50 & 0 \\
\hline 1.25 & .33 & 2.49 & 50 & Bottom \\
\hline 1.44 & .24 & 2.66 & 55 & 0 \\
\hline 0.98 & .50 & 2.92 & 55 & Bottom \\
\hline 0.48 & .53 & 1.61 & 60 & 0 \\
\hline 0.83 & .56 & 3.24 & 60 & Bottom \\
\hline 1.60 & .54 & 3.77 & 65 & 0 \\
\hline 0.77 & .55 & 2.30 & 65 & Bottom \\
\hline 0.92 & .35 & 2.66 & 70 & 0 \\
\hline 1.11 & .33 & 2.13 & 70 & Bottom \\
\hline 1.43 & .27 & 3.24 & 25 & 10 \\
\hline 0.77 & .29 & 2.13 & 35 & 10 \\
\hline 1.18 & .29 & 2.24 & 45 & 10 \\
\hline 1.68 & .18 & 2.64 & 55 & 10 \\
\hline 1.90 & .25 & 3.42 & 65 & 10 \\
\hline 0.79 & .30 & 1.32 & 25 & 20 \\
\hline 1.81 & .52 & 3.88 & 35 & 20 \\
\hline 1.51 & .12 & 2.07 & 45 & 20 \\
\hline 2.20 & .18 & 3.37 & 55 & 20 \\
\hline & & & \\
\hline
\end{tabular}




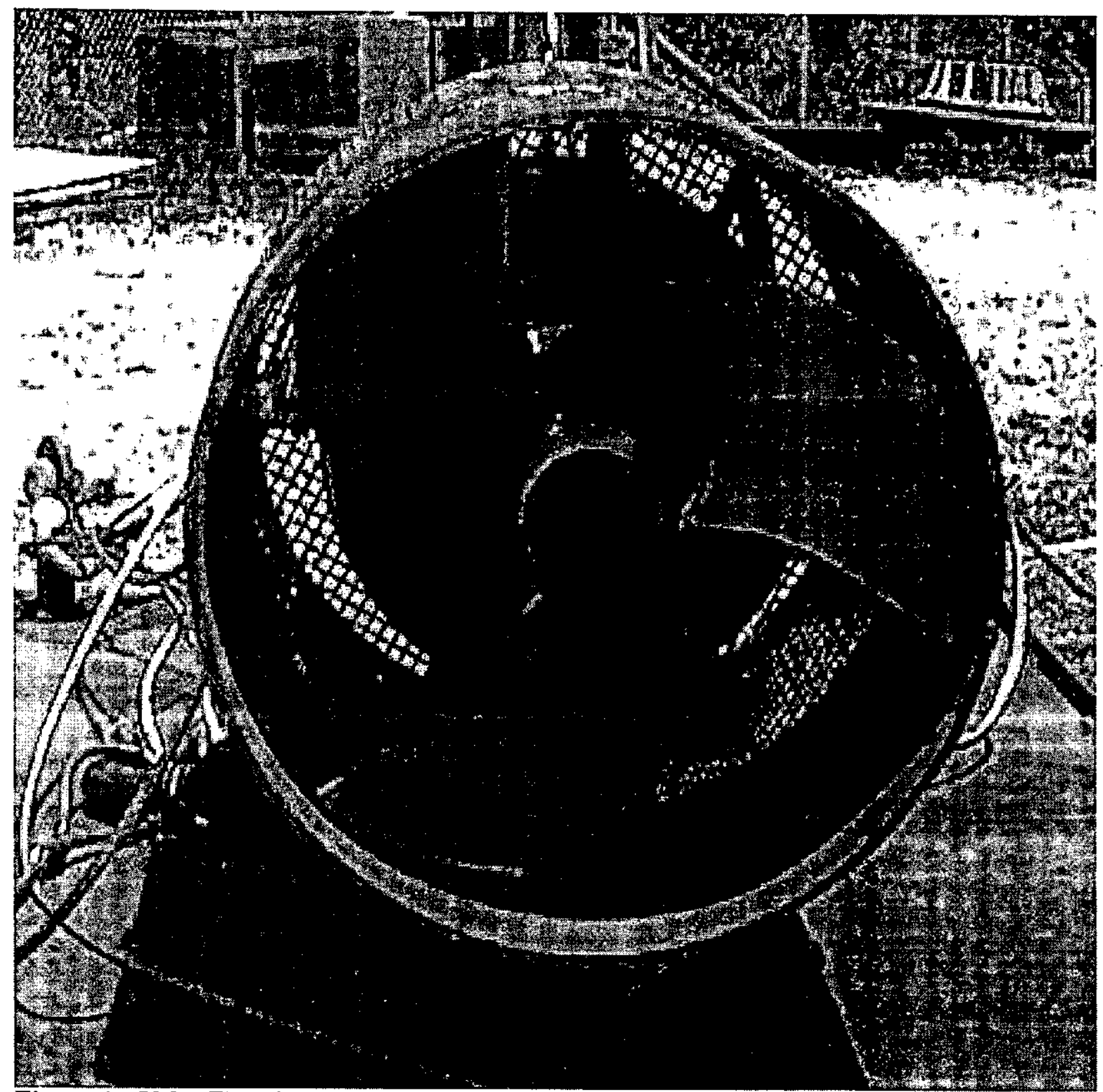

Figure 1. $50 \mathrm{hp}$ Flygt Mixer 


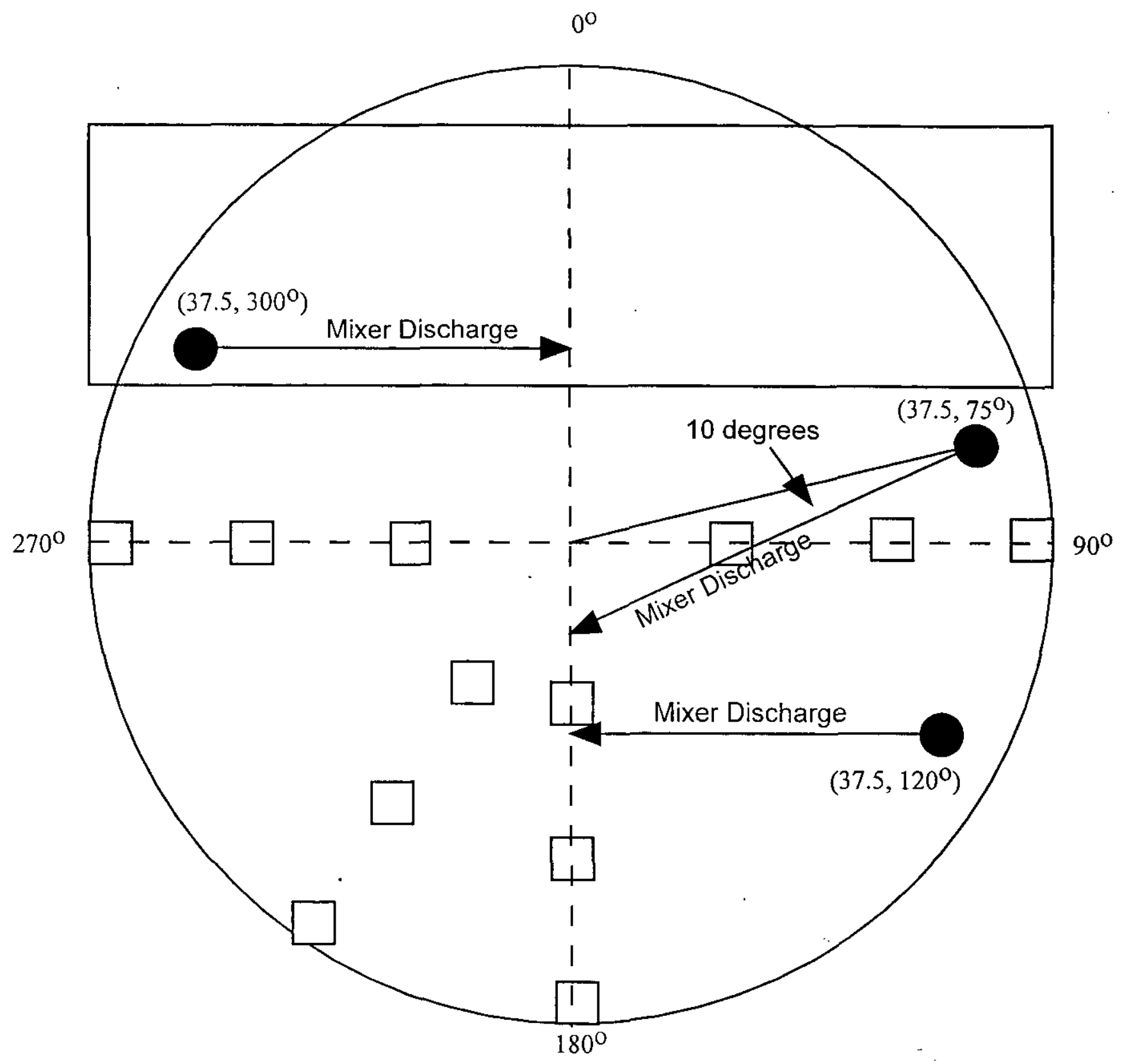

$85 \mathrm{ft}$

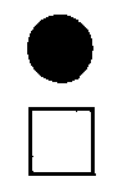

Mixer

Water depth $4 \mathrm{ft}, 3 \mathrm{ft}, 5 \mathrm{ft}$

Figure 2. Mixer Layout for Test 4

Velocity Sampling Point . 